\title{
THE PROTEIN METABOLISM IN SMALL ANIMALS WITH CHRONIC RENAL FAILURE AND ITS CORRECTION
}

\author{
Liliia Kalachniuk \\ Department of Biochemistry named after Academician M. F. Hulyi \\ National University of Life and Environmental Sciences of Ukraine \\ 15 Heroiv Oborony str., Kyiv, Ukraine, 03041 \\ kalachnyuk_liliya@nubip.edu.ua \\ Luhova Yeseniia \\ Department of Biochemistry named after Academician M. F. Hulyi \\ National University of Life and Environmental Sciences of Ukraine \\ 15 Heroiv Oborony str., Kyiv, Ukraine, 03041 \\ lugovaya.yeseniya@gmail.com \\ Maliuk Inna \\ Department of Biochemistry named after Academician M. F. Hulyi \\ National University of Life and Environmental Sciences of Ukraine \\ 15 Heroiv Oborony str., Kyiv, Ukraine, 03041 \\ inna_nikolaevna@ukr.net
}

\begin{abstract}
Chronic renal failure (CRF) is often diagnosed in cats and dogs of old age. CRF is a consequence of metabolic deviations because of diseases (for example, generalized atherosclerosis, hypertensive disease, diabetes and others) and incorrect feeding. CRF is also a result of the delayed diagnosis of diseases of the urinary system and/or inadequate treatment.

Aim of research. To study the biochemical parameters of protein metabolism that are important for determination of CRF stages and sub-stages in old small animals during correction of metabolic deviations.

Materials and methods. There were analyzed biochemical indices (creatinine concentration in the blood serum; the ratio of protein/creatinine (UP/C) in the urine) and measured arterial blood pressure in 5 cats and 5 dogs with chronic renal failure selected from patients of the clinic according to medical history, clinical examination and special analysis.

Results. It was analyzed CRF stages and sub-stages classification according to the International Renal Interest Society (IRIS). According to the date of creatinine concentration in the blood serum, CRF of the second stage was observed in 5 cats $(140-250 \mu \mathrm{mol} / \mathrm{L})$ and $3 \mathrm{dogs}(125-180 \mu \mathrm{mol} / \mathrm{L})$, and of the third stage - in 2 dogs $(181-440 \mu \mathrm{mol} / \mathrm{L})$. The CRF sub-stage as "without proteinuria" $(\mathrm{UP} / \mathrm{C}<0.2)$ was identified in 1 cat, "marginal proteinuria" $(\mathrm{UP} / \mathrm{C}$ 0.2-0.4) - in 1 cat and "proteinuria" $(\mathrm{UP} / \mathrm{C}>0.4)-$ in 3 cats, and as "proteinuria" (UP/C $>0.5)$ - in 5 dogs.

Conclusions. An important step of the successful treatment of CRF is the definition of the stages and sub-stages according to IRIS based mostly on the measurements of biochemical indices in the blood and urine of sick animals - indicators of creatininemia and proteinuria, a change of which was caused mainly by metabolic processes of proteins under influence of exogenous factors (the traditional treatment of CRF plus enalapril and diet nutrition).
\end{abstract}

Keywords: chronic renal failure, protein metabolism, cats, dogs.

\section{Introduction}

Chronic renal failure (CRF) occurs because of delayed diagnosis of diseases of the urinary system of cats and dogs and/or inadequate treatment. CRF is caused by progressive destruction of nephrons in any progressive kidney disease $[1,2]$. In 1 of 3 cats and 1 of $10 \mathrm{dogs}$, there is CRF, which is a common cause of morbidity and death, mostly cats [3]. Usually the etiology of chronic renal failure in small animals is unknown, and the primary factor is missing despite the fact that kidney damage remains and progresses. An age, genetic predisposition, environmental pollutions and diseases of non-contagious and contagious etiology are the most common factors that contribute to the occurrence of CRF $[4,5]$. 


\section{Aim}

To study the biochemical parameters of protein metabolism that are important for determination CRF stages and sub-stages in old small animals during correction of metabolic deviations.

\section{Materials and methods}

Experiments were carried out in the veterinary clinic "Zooliuks" in Kyiv during the term: from September 2014 until January 2016. There were selected 5 cats and 5 dogs with chronic renal failure (according to medical history, clinical examination and special analysis) from patients of the clinic.

The blood of the animals were taken from the saphenous vein of the forearm in a dry, disposable, clear tube and kept to clot formation at a temperature of $37{ }^{\circ} \mathrm{C}$. After coagulation, the samples were centrifuged at $3000 \mathrm{rpm}$ for $10 \mathrm{~min}$, and the blood serum was taken off to determine the biochemical parameter.

Arterial blood pressure was measured by oscillographic tonometry putting the cuff on the root of animal tail. The cuff was connected to the electronic unit and air injection-holder.

Urine sample was taken by cystocentesis under ultrasound control, centrifuged at $1500 \mathrm{rpm}$ for $10 \mathrm{~min}$; the supernatant was collected and biochemical indices were measured.

Creatinine concentration in the blood serum and UP/C in the urine were performed using semi-automatic analyzer Rayto RT-9200 and a set of reagents Global Diagnostics.

The cats were under traditional treatment. In addition to the traditional treatment of chronic renal failure in the cats, antiproteinuric effect was provided by administration of enalapril per os in a dose of $0.25-0.5 \mathrm{mg} / \mathrm{kg}, 1-2$ times/day. The animals were under observation for 2 and 12 weeks [6].

During experimental period, health state of cats and dogs was under investigation depending on their feeding on ordinary diet and Royal Canin "Renal" diet $[7,8]$.

\section{Results of research}

According to medical history, clinical examination and special analysis, there were selected 5 cats and 5 dogs with chronic renal failure from patients of the clinic.

It was defined stages of chronic renal failure in small animals according to IRIS classification. 5 cats and 3 dogs had CRF of the second stage (creatinine concentration in the blood serum was $140-250 \mu \mathrm{mol} / \mathrm{L}$ and $125-180 \mu \mathrm{mol} / \mathrm{L}$, respectively), and $2 \mathrm{dogs}$ had CRF of the third stage (creatinine concentration in the blood serum was 181-440 $\mu \mathrm{mol} / \mathrm{L})($ Fig 1, 2).

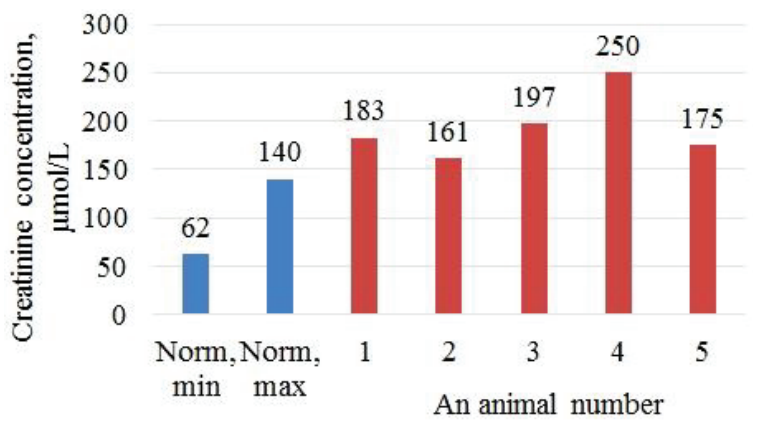

Fig. 1. Concentration of creatinine in the blood serum of cats $(n=5)$

There are data of arterial blood pressure on Fig. 3. The arterial blood pressure data show that cats had the third ("high risk") sub-stage of CRF (diastolic blood pressure was $\geq 130$ and systolic blood pressure was $\geq 180 \mathrm{~mm} \mathrm{Hg}$ ) and dogs had the second ("mild risk") CRF sub-stage (diastolic blood pressure was 100-119 and systolic blood pressure was 160-179 mm Hg).

The ratio of protein/creatinine (UP/C) in the urine of cats was ranged from 0.26 to 7.1 and dogs - from 0.5 to 6.9. According to IRIS classification, it was identified such CRF sub-stages as "without proteinuria" (UP/C<0.2), "marginal proteinuria" (UP/C 0.2-0.4) and "proteinuria" (UP/C >0.4) in 1,1 and 3 cats, respectively, and "proteinuria" (UP/C $>0.5)$ in 5 dogs (Fig. 4, 5). 


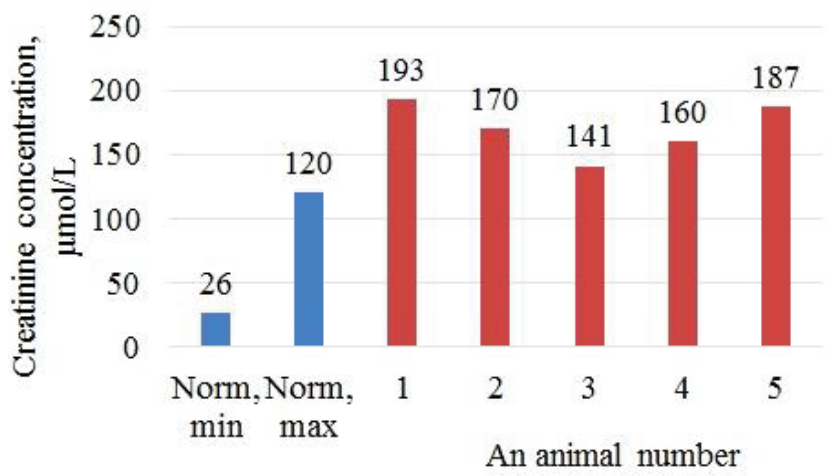

Fig. 2. Concentration of creatinine in the blood serum of dogs $(n=5)$

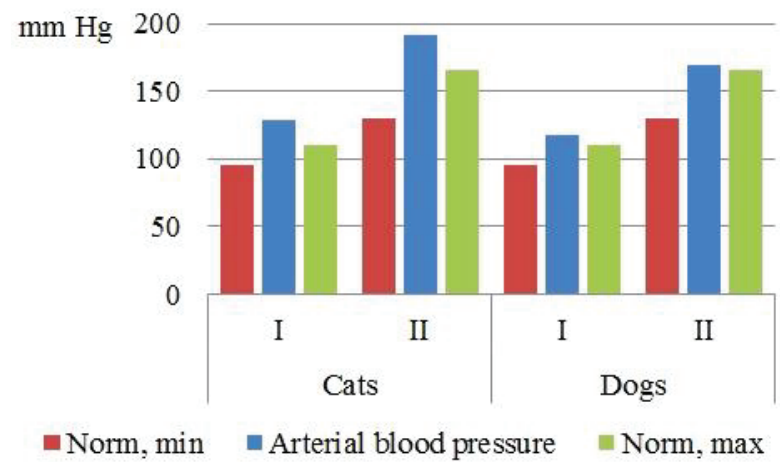

Fig. 3. The arterial blood pressure of cats and dogs in comparison with the norm.

I - Diastolic blood pressure, II - Systolic blood pressure

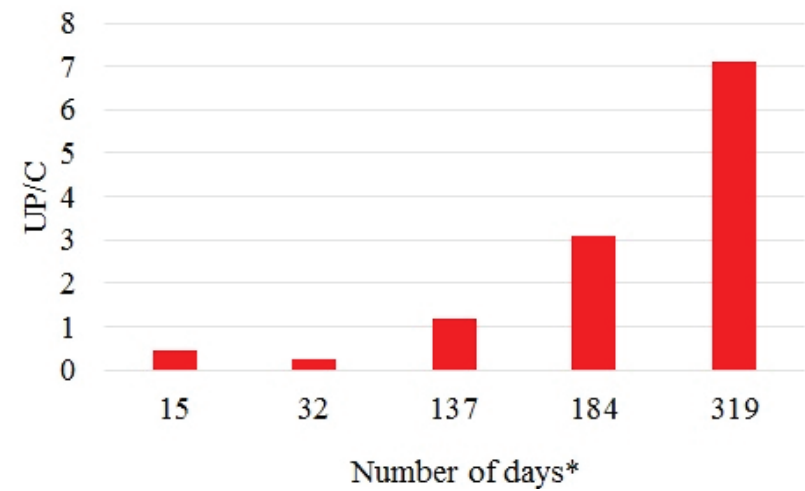

Fig. 4. The ratio of protein/creatinine (UP/C) in the urine of cats, where * - number of days from diagnosis to its determination at last control patient reception or identification of stable remission

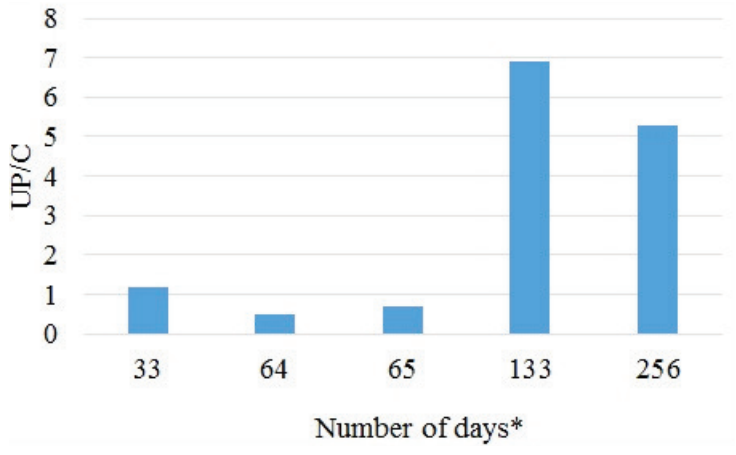

Fig. 5. The ratio of protein/creatinine (UP/C) in the urine of dogs, where * - number of days from diagnosis to its determination at last control patient reception or identification of stable remission 
Earlier, we studied the treatment influence on the indices of protein metabolism [6]. In addition to the traditional treatment of CRF in the cats, antiproteinuric effect was provided by administration of enalapril. After 2 and 12 weeks of the experiment, in the urine of cats, it was repeatedly measured UP/C ratio, which fell to 0.2 in $20 \%$ and $60 \%$ of animals, respectively.

Royal Canin "Renal" diet was the one of important exogenous factors of decrease of CRF progression, reduced the duration of treatment in almost 4 times according to our previous work [7].

\section{Discussion of investigation}

Creatininemia, arterial hypertension and proteinuria are one of the main indices of progression of chronic renal failure in small animals. Diagnosing them in small animals with CRF is an important step to establish the stages and sub-stages of disease according to International Renal Interest Society (IRIS).

CRF stages are determined in order to carry out an appropriate treatment and monitoring. Diagnosing the stages of CRF is based on creatinine concentration in the blood serum. Using algorithms recommended by IRIS, the doctor may prescribe some type of treatment and predict the course of disease $[9,10]$.

Then CRF sub-stages were determined depending on the parameters of proteinuria and arterial blood pressure. The CRF sub-stages definition depending on the arterial blood pressure is respectively classified according to the measurement to risk of target organ damage [10-12].

Measuring blood pressure is an important step for determining the diagnosis of chronic renal failure, since hypertension has a negative effect on the kidneys due to the increased hydrostatic pressure in glomerular loops, leading to functional disorders, and later to the anatomical and morphological changes.

The final determination of CRF sub-stages is based on multiple blood pressure measurements (it is desirable that there were several patients in different days; it's also permissible to focus on one patient, whose pressure was measured with a difference of two hours) [10, 11].

The importance of CRF sub-stages determination depending on indices of proteinuria is to identify exactly the causes of proteinuria (before renal, renal, after renal) [10, 13]. International Renal Interest Society divides the daily proteinuria in cats and dogs, which is determined by the ratio of protein/creatinine in the urine into three types: "without proteinuria", "marginal proteinuria" and "proteinuria" [10, 14].

Administration of enalapril with antiproteinuric effect decreased UP/C to 0.2 in $20 \%$ of cats under the traditional treatment of CRF after 2 weeks and in $60 \%$ of animals after 12 weeks. Enapril as other angiotensin-converting enzyme inhibitors decreases the glomerular capillary pressure, has antiproteinuric effect, tends to delay the progression of CRF and to limit the extent of renal lesions [15].

Stabilization of health state in cats and dogs fed on ordinary diet was observed after 210 and 195 days of treatment, respectively. The treatment of cats and dogs together with feeding according to Royal Canin "Renal" diet lowered indices of protein metabolism for 30 and 50 days, respectively, and shortened the time of health stabilization approximately in 4 times comparing to the one with feeding animals on ordinary diet $[7,8,16-21]$.

\section{Conclusions}

The quantitative value of $\mathrm{UP} / \mathrm{C}$ in the urine of cats and dogs $(>0.4$ and $>0.5$, respectively) shows the necessity to diagnose and monitor the disease on CRF in small animals.

The definition of the stages and sub-stages according to IRIS based mostly on measurements of biochemical indices in the blood and urine of sick animals is very important for successful treatment of CRF. Indicators of creatininemia and proteinuria show changes caused mainly by metabolic processes of proteins under the influence of exogenous factors such as the traditional treatment of CRF plus enalapril and diet nutrition.

\section{References}

[1] Bainbridzh, D., Elliot, D. (2003). Nefrologiia i urologiia sobak i koshek. Moscow: AKVARIUM LTD, 272. 
[2] Denisenko, V. N., Kesareva, E. A., Kruglova, Iu. S., Kalmykova, O. V. (2007). Diagnostika i lechenie pochechnoi nedostatochnosti u sobak i koshek: Metodich. ukazaniia. Moscow: FGOU VPO MGAVMiB, 34.

[3] Leonard, R. (2014). Analiz na kreatinin: nadezhen ili bespolozen? Sovremennaia veterinarnaia meditcina, 2, 34-41.

[4] Polzin, D. J. (2007). 11 guidelines for conservatively treating chronic kidney disease. Veterinary Medicine, 102 (12), 788-799.

[5] O’Neill, D. G., Elliott, J., Church, D. B., McGreevy, P. D., Thomson, P. C., Brodbelt, D. C. (2013). Chronic Kidney Disease in Dogs in UK Veterinary Practices: Prevalence, Risk Factors, and Survival. Journal of Veterinary Internal Medicine, 27 (4), 814-821. doi: 10.1111/jvim.12090

[6] Luhova, Ye., Kalachnyuk, L. (2016). Proteinuria in the cats with chronic kidney disease and its correction. 2-nd International Scientific Conference of Veterinary Medicine Students. Warsaw, 47.

[7] Luhova, Ye. S., Prys-Kadenko, V. O., Kulichenko, A. O., Kalachniuk, L. H. (2016). Diet-therapy of small animals with chronic renal failure. Scientific Messenger of LNU of Veterinary Medicine and Biotechnologies, 18/3 (70), 178-181. doi: 10.15421/nvlvet7042

[8] Trademark "Royal Canin". Available at: http://www.royalcanin.com.ua/

[9] Lees, G. E., Brown, S. A., Elliott, J., Grauer, G. F., Vaden, S. L. (2005). Assessment and Management of Proteinuria in Dogs and Cats: 2004 ACVIM Forum Consensus Statement (Small Animal). Journal of Veterinary Internal Medicine, 19 (3), 377-385. doi: 10.1111/j.1939-1676.2005.tb02713.x

[10] International Renal Interest Society. Available at: http://www.iris-kidney.com/

[11] Leonard, R. (2015). Nefropatii sobak i koshek i arterialnaia gipertenziia. Sovremennaia veterinarnaia meditcina, 1, 28-38.

[12] Chew, D. J., DiBartola, S. P., Schenck, P. A. (2010). Canine and Feline Nephrology and Urology. Philadelphia: Saunders, 528.

[13] Harley, L., Langston, C. (2012). Proteinuria in dogs and cats. The Canadian Veterinary Journal, $53(6), 631-638$.

[14] Adams, L. G., Polzin, D. J., Osborne, C. A., O’Brien, T. D. (1992). Correlation of Urine Protein/ Creatinine Ratio and Twenty-Four-Hour Urinary Protein Excretion in Normal Cats and Cats with Surgically Induced Chronic Renal Failure. Journal of Veterinary Internal Medicine, 6 (1), 36-40. doi: 0.1111/j.19391676.1992.tb00983.x

[15] Lefebvre, H., Brown, S., Chetboul, V., King, J., Pouchelon, J.-L., Toutain, P. (2007). AngiotensinConverting Enzyme Inhibitors in Veterinary Medicine. Current Pharmaceutical Design, 13 (13), 1347-1361. doi: $10.2174 / 138161207780618830$

[16] Fascetti, A. J., Delaney, S. J. (2012). Applied Veterinary Clinical Nutrition. UK, Chichester: Wiley-Blackwell, 1, 251-263.

[17] Filippov, Iu., Poziabin, S., Belogurov, V. (2014). Dietoterapiia koshek s khronicheskoi pochechnoi nedostatochnostiu. Sovremennaia veterinarnaia meditcina, 4, 8-9.

[18] Kolodii, I. V., Ermakov, A. M. (2010). Dietoterapiia pri khronicheskoi pochechnoi nedostatochnosti u sobak. Vet. Patologiia, 3, 54-57.

[19] Hughes, K., Slater, M., Geller, S., Burkholder, W., Fitzgerald, C. (2002). Diet and lifestyle variables as risk factors for chronic renal failure in pet cats. Preventive Veterinary Medicine, 55 (1), 1-15. doi: 10.1016/s0167-5877(02)00088-0

[20] Elliott, D. A. (2006). Nutritional Management of Chronic Renal Disease in Dogs and Cats. Veterinary Clinics of North America: Small Animal Practice, 36 (6), 1377-1384. doi: 10.1016/j.cvsm.2006.08.011

[21] Laflamme, D. P. (2008). Pet Food Safety: Dietary Protein. Topics in Companion Animal Medicine, 23 (3), 154-157. doi: 10.1053/j.tcam.2008.04.009 